Lamees Mohamed El-Gafy

Assistant Professor

English Dept.

Faculty of Al-Alsun

Minia University, A.R.E

\title{
The Language of Silence in Post-Colonial Writing: \\ David Malouf's An Imaginary Life \& \\ Keri Hulme's The Bone People
}

Traditionally silence is perceived as withdrawal or as a withholding of meaning, hence the desire to break that silence in order to recover its hidden significance The producers of post-colonial writing are burdened by a constant awareness that the cultural myths that inform their writing and the language they use are vehicles for a provisional truth, which has been dictated by the demands of the empire. The necessary abrogation of the received language creates, for the postcolonial writer, a crisis of authority, which finds textual representation in figures of silence. Keri Hulme's The Bone People and David Malouf's An Imaginary Life, both thematize the writer's necessary quest beyond the boundaries of conventional language through the relationship of an artist-protagonist with a mute child. The progress of this interaction may be seen as an emblem of the writer's examination of language and related revision of the dialogue between self and other which constitutes the artistic exchange.

In both novels, the mute child is initially perceived as a mystery which can be solved through the discovery of its hidden origins. The failure of conventional social and linguistic codes to classify the child leads both protagonists to recognize the limitations of those codes and to question the systems by which their own identities are defined. They recognize what appears to be the greater authenticity of indigenous culture, represented by the Maori in The Bone People and the barbarians in An Imaginary Life. Integral to this acknowledgment, however, is the recognition that this voice cannot be rendered in the terms of the colonial discourse, and the ultimate realization that the temporal priority of the indigenous language does not attribute to it an organic grounding in place which somehow guarantees its authenticity. The only voice 
capable of reporting the post-colonial experience, then, is that which articulates the space.

Malouf's novel, An Imaginary Life, retells the story of the Roman poet Ovid's exile from Rome - the centre of culture at the time - to the bleak wilderness at Tomis, near the Black Sea. Here we have a person absolutely dependent on language - a poet - forced to live in a world where the landscape, the language, all is alien him. In her book Sheer Edge, Karin Hansson points out that against this background, Malouf's novel about the exiled Roman poet who finds new roots in foreign soil, can be seen as illustrative of an Australian, and generally, the colonial dilemma, largely related to linguistic, cultural and psychological identity (21). Eventually, with the assistance of a wild child, Ovid comes to accept his new surroundings. He does this by using the power of language and imagination to construct this new world for himself in a way that is meaningful.

Therefore, the transforming power of language is a primary theme in Malouf's work; but language is also seen as a potential hindrance. The worst torment for Ovid is the isolation caused by his inability to communicate. His civilised tongue, Latin, is unknown, and he cannot speak the Getae language. He begins to lose a solid sense of identity. Ovid's sophistication makes it difficult for him to be opened to the different languages and silences of Nature - until he is taught how to do so by the Child.

Gradually, through imagination, which provides a kind of belief and faith, he is able to re-make, re-constitute the world. At this time of the story comes the Child who is a literal as well as symbolic child. Literally, he is a mysterious wolf-boy living with the deer which the Getae hunt. In this time Ovid has become increasingly reconciled with his life on the margins, has learned to speak the Getae language, to appreciate the beauty and the terror of the natural world, to parake in the daily work and craft of the village. The language, which the Child represents, is not a language in any real sense, as much as it evades the function of any language to define. to make distinctions between things. It is what Ovid calls the language of childhood, a wordless communicative form which is free from binding structures and which expresses no distinction, but 
oneness with the external world, only in an unconscious state likes to recall this tongue:

The true language, I know now, is that speech in silence in which we first communicated, the Child and I, in the forest, when I was asleep. It is the language my tongue almost rediscovers and which would, I believe, reveal the secrets of the universe to me. When I think of my exile now it is from the universe... The language I am speaking of now, is a language whose every syllable is a gesture of reconciliation. ( $A n$ Imaginary Life 97-98)

Having already suffered, through his exile, the invalidation of his codes of meaning, Ovid readily admits that the Child - who, significantly, remains nameless - defies classification. He observes:

It exceeds my imagining, that sharp little face with its black stare, and I think how poorly my poetry, with its elegant fables and pretty, explainable miracles compares with the accidental reality of this creature who must exist (if he does exist) not to impress but simply because he has somehow tumbled into being. (An Imaginary Life 50)

If Ovid seems content to accept that the Child's existence thus far has been arbitrary, he is determined that it should not continue to be so. He feels compelled to identify the Child, and teach him to identify himself, as a humana recognition which must be affected through language. He observes, "I am filled with tenderness, an immense pity for him, a need to free him into some clearer body that is like a pain in my own" (77). Perhaps without realizing it, Ovid is acknowledging here, not just compassion, but his own vested interest in the Child's accession to the symbolic realm.

The Child at first remains trussed and animal-like. Eventually some threads of connection are made, and Ovid sees his task as to help the Child understand his human rather than animal identity. Vital to the Child's metamorphosis into a social being is Ovid's decision to teach him the language of the Getae. This decision is motivated by Ovid's feeling that "[speech] is the essential. I have hit at the very beginning on the one thing that 'vill reveal to him of what kind he is' (92). Yet attached to the decision to teach the Child language is a difficulty 
which Ovid never quite overcomes. On the one hand, he is caught up in the need to show the Child "that he is made as I am": that he is a social being. On the other hand, his learning of language will mean that the Child is no longer joined consciously to the world about him: the very quality which had drawn Ovid to him will be lost. Ovid's own lessons with the Child promise a simpler outcome; in contrast to the Child's entry into the social world of definitions and boundaries, Ovid finds himself "more and more often slipping back into my own childhood" (82). This retreat is not merely backwards into his past, but is also inward into "the dimensions of myself" (95). Through the Child he is learning the "true language" (97) that wordless state in which everything "hums in sympathy" (104).

Ovid's attempts to articulate the Child's existence appear, at least initially, to be somewhat more successful. The Child has a weird ability to imitate animals and birds, which skill, Ovid notes approvingly, can surely be turned to the acquisition of language. As Ovid gradually comes to notice, however, the Child possesses something other than a mimic's skill to copy something outside himself; in imitating a bird, actually becomes the bird, allowing it to speak through him. As Ovid observes, "He has no notion of the otherness of things" (96). In view of this realization, Ovid decides to teach the Child not Latin but the barbarian tongue, which:

... is equally expressive, but what it presents is the raw life and unity of things... Somehow it seems closer to the first principle of creation, closer to whatever force it is that makes things what they are and changes them into what they would be. (An Imaginary Life 65)

As the lessons progress, however, Ovid realizes that even this language is inadequate to contain the Child's experience. He tries to perceive the world as the child does - as an extension of himself - but finds he cannot, reasoning:

my knowing that it is sky, that the stars have names and a history, prevents my being the sky. It rains, and I say 'it rains'... I I try to think as [the Child] must: 'I am raining..., and am immediately struck with panic, as if, in losing hold of my separate and individual soul. in shaking the last of it off trom the tip of my little finger, I might tind myself lost out there in 
the multiplicity of things, and never get back. (An Imaginary Life 96)

The approach of winter means that Ovid and the Child will have to move out of their separate hut into the main hut. Disease and fever strike the Child. At the height of his illness, he speaks a single word, and the others see this as fearful proof that he has entered one of their spirits during sleep. In a last miraculous series of changes, of transformations, they travel across the still-frozen river, and into the 'real unknown'. Ovid no longer fears change but welcomes it as he approaches death. In a reversal of roles, the Child now leads him and nurtures him in his last days. They travel into what seems a great emptiness, a wasteland, a wilderness, yet that emptiness, that wildness, promise, also, a spiritual freedom. In this final stage, there is no more dreaming: the conscious and unconscious minds have become one. Ovid's spirit seems to expand and fill the landscape, and he seems to see from within and without his body simultaneously. In this journey of rediscovery, the Child is the leader, directing Ovid "further from the last inhabited outpost of the known world, further from speech even, into the sighing grasslands that are silence" (145). Guided by the Child, Ovid feels ever closer to that initial but lost state of oneness with the world:

I am entirely reconciled to the process. I shall settle deep into the earth, deeper than I do in sleep, and will not be lost. We are continucus with earth in all the particles of our physical being, as in our breathing we are continuous with sky. Between our bodies and the world there is unity and commerce. (An imaginary Life 147)

He dies - and he is all ages, a child and an old man - while he sees the Child walking from the earth, from the water, out into the air, above all. The transcendental movement of the Child is paralleled with Ovid's metamorphosis into death, and may signify a union of self and other, and death which is rebirth. This ending gestures towards an imaginary space where the boundaries between speech and silence, centre and edge, origin and destination can be crossed and overcome. According to Amanda Nettelbeck in her book Reading David Malouf, this might reflect a romantic idealism, but it might also constitute a political statement. especially in the context of contemporary Australia where 
boundaries of cultural identity are currently open to review. Not only are Australians rethinking their cultural position in the southern hemisphere, but also, within Australia, they are reconsidering the cultural makeup of the community and its impact on the landscape (41).

Language was seen as imperfect, degenerate, a notion which implies the possibility of some perfect or original or uncontaminated expression. Thus a connection is drawn between a language once pure and an uncorrupted culture or primitive state. The child is used to mediate a contradiction - that of seeing modern society as degenerate while wishing to preserve its superiority over an otherwise idealised primitive state. The movement throughout An Imaginary Life is from civilised language to primitive language, to a pictorial and natural language, to a state beyond words, to silence.

Therefore, the Child in Malouf's novel plays an important role, he is part of nature and the animal world, existing in harmony with that world, and taking on some of its characteristics. Nature, too, shares some of the Child's characteristics - absence of verbal language, innocence, wildness, removal from artifice. The Child stands for wholeness, integrity - as against fragmentation, separation, alienation. When Ovid tries to save the lost Child, through domestication and verbal language, the Child loses that wholeness, Ovid misguidedly colonises the Child.

Keri Hulme (1947- ) is a New Zealand novelist, short-story writer and poet. She was born in Christchurch, of mixed Maori, Orkney Island Scottish, and English parentage. She has identified most strongly with her Maori origins, though they only represent one-eight of her ancestry. Her mother, Mere, was of Orkney Scots and Maori descent - the Maori are the original inhabitants of New Zealand. Hulme's father John W. was a carpenter and businessman - he died when Hulme was eleven. Her first novel, The Bone People (1983), lifted the author from obscurity to world fame. In the novel, Hulme blended naturalism and poetry, and showed her deep understanding of the spiritual legacy of Mlaori culture (Bateman Encyclopaedia).

The Bone People is ser on the wild and isoiated West Coast of the South Isiand where Hulme, herself a New Zealancier of Maori, Scottish and English 
descent. still lives. She weaves the history, heritage and mysticism of the Maori people into the story along with symbols from their culture and from the Christianity that arrived in New Zealand as part of the Pakeha (European) colonization. The language, too, is a post-colonial hybrid of Maori and English The characters are both human and part of the complex symbolism that underpins the book and the post-colonial mixture of Maori and European culture and myth is fascinating and worth probing.

The Bone People focuses on three main characters. Out of the unconventional trinity she created, Keri Hulme has made what is at once a mystery, a love story, and an ambitious exploration of the zone where Maori and European New Zealand meet, clash, and sometimes merge. The central character is Kerewin Holmes (a character similar to Hulme) who lives isolated in a seaside tower, a mute child named Simon, and his abusive stepfather Joe Gillayley.

Hulme explains: "What I was doing in The Bone People was getting my head straight on questions like: What happens to outcasts? Is there any point to life? What would happen if Maori spiritual presence was resurrected in this land of ours? She describes her story as a deliberate attempt to manufacture New Zealand myth, to blend real and invented Maori legends with European literary style, harmonizing both of her country's cultural influences (Contemporary Literary Criticism 158).

The protagonist Kerewin Holmes is a painter who can no longer create. She is par Maori, part European and estranged from her family. She lives as a hermit in a tower-shaped house, and undergoes a spiritual renewal. Her solitary life is interrupted by the arrival of a mute little boy called Simon Peter. An orphan who had survived a shipwreck, Simon is the adopted son of Joe Gillayley, a Maori labourer who carries his own burden of loss and bitterness. Joe is similarly part Maori, likewise cut from his family, but by death rather than estrangement as having lost his wife and child. The potential link between Kerewin and Joe is Simon who carries within him the scars of the violence practiced on him in his childhood, expressed in his dumbness, his loss of memory, and his tlashes of hysteria and violence; these are the other side of his positive yualities, his need to love and be loved, needs so deep that he will take 
on suffering to realize them. As Kerewin submits to Simon's natural charm, she also falls under the spell of his Maori foster father Joe, who rescued the boy from a shipwreck and now treats him with an unsettling mixture of tenderness and brutality.

Kerewin fails initially to define Simon, and so confronts the limitations of the system which informed her own consciousness. She approaches an acknowledgment of the silence of alterity, but is saved from actually entering that destabilizing space by almost mystical apprehension of the Maori spirituality which had been excluded by her Pakeha lifestyle. Thus while Ovid's journey ultimately ends with ego condemnation, transcendence and a diffusion of meaning, Kerewin's quest involves the penetration of multiple layers of meaning to their vital core, and ends with ego confirmation and a new social vision characterized by a reconciliation of Maori and Pakeha culture.

In both novels, the silence of the mute child may be seen as a metaphor of the cultural and linguistic splits prevalent in post-colonial society, which requires acknowledgement by the artist seeking voice of authenticity. Such acknowledgment precedes Ovid's metamorphosis into a new consciousness. Kerewin, however, avoids the need to acknowledge this silence by achieving a degree of self-enlightenment which evidently enables her to repair the split between Maori and Pakeha cultures. Simon is reinscribed with Kerewin's voice, and is thus finally incorporated into her enlightened personal vision. In its failure to acknowledge the essential untranslatability - in either Maori or Pakeha terms-of Simon's silence, the validity of this vision, which informs the conclusion of the book, must be called into question.

Both Kerewin and Ovid are artists who have enjoyed a measure of success, and whose pride in their personal achievements amounts to a belief in a historical existence. While Ovid's banishment confirms his meaninglessness, Kerewin's self-imposed exile seems actually to provide a solution to the problem of self-definition. Exile, for Ovid, signifies the rupture of an identity, the integrity of which had been guaranteed by its construction from Latin, "that perfect tongue in which ail things can be spoken" (. 1 n Imagmaly Life 21). Such integrity may be seen as characteristic, not of Latin itself. but of the 
homogenous which fostered it. Living in post-colonial New Zealand, Kerewin never had access to a construction-or an illusion-of unequivocal significance. Of mixed heritage herself, Kerewin is acutely aware of the gaps and tensions engendered by the continuity of different meaning systems, and is thus denied the security of belief in a 'pure' exchange. For Kerewin, then, the only possible means of preventing the danger of meaninglessness is by building herself an unassailable tower wherein she secures the least evasive audience she can find herself.

There is the initial movement between the three characters, Simon acting as the link to draw Kerewin out of her tower, and Joe away from drink and violence, making Kerewin aware of Joe's violence and involving her with him to stop it.. Her curiosity is not satisfied by their exchange; though Simon can write, he shows a clear aversion to the activity, relying instead on a sign language that is as unconventional as Kerewin's own speech. This requires her complete attention, which she grants unwillingly and even defensively, wondering if "maybe all this is like a fine drawn duel to him, words against his miming" (The Bone People 31). Telling the bewildered Simon 'Obfuscation is my trade' (The Bone People 24), Kerewin launches a dazzling verbal attack, which is dissipated in its confrontation with a discourse so far removed from the sphere of symbolic power as to be unable to recognize its existence. For Simon, tormented by a memory of a "haunting terrible voice, that seemed to murmur endearments all the while..., hands skilfully and cruelly hur him" (The Bone People 5), words have always been insignificant. While neither the reader nor Kerewin ever learns the reason for his muteness (for which there is no physiological explanation), it is clearly connected to his early victimization, and entails, not merely the absence of the faculty of speech, but absolute symbolic impotence. Touch, then, ss the only reliable reality gauge for Simon, whose identity, unlike Kerewin's, is confirmed not through its difference to and separateness from others, but through his interconnection with them. His eagerness to touch Kerewin and hold her hand disturbs her, as it cancels out the distance that would asleep is she able to bring an emotionally neutral abstraction. Only when he is harmiessly, and even ping to bear the power of synecdoche to render him ot his sandal. 
Susie O'Brien, in her essay "Raising Silent Voices", explains that Kerewin's artistic appropriation of Simon is reminiscent of the colonial practice of othering, whereby the terms of imperial identity are reinforced by a simultaneous assimilation and depersonalization of the colonial subject. Paradoxically, this process of reduction so misrepresents the subject that the definition collapses under its own contradictions, so throwing the whole signifying system into radical question (83-84). The emptiness of Kerewin's verbal victory over Simon reveals the psychoanalytical principle that ego confirmation depends ultimately on its symbolic reflection in the expression of the Other. The symbolic impotence of the mute child renders him incapable of satisfying the desire of the speaker for such an affirmation of power; the child is rather, as a mirror, which, instead of providing the expected reassurance of a solid image, absorbs everything that confronts it, reflecting nothing but absence. Simon's multiple scars bear testimony to the frustration experienced by those who would leave an indelible impression of their power. Both Ovid and Kerewin reject such crude attempts at suppression, employing, instead the gentler violence of words as a means of translating their subjects into known and thus colonizable - entities.

That Kerewin has not attained that level of understanding with respect to Simon is demonstrated by her persistent refusal to acknowledge his difference. Because of her Pakeha origin, she cannot stand for the attitude of indifference which Simon (Like the Child) consistently demonstrates towards this selflegitimizing power. Evidence of Simon's hesitation towards self-expression is provided on the occasion of one of his early visits, during which Kerewin gives him paper and charcoal to draw with while she works at her own art. Her own drawing finished, she rejoices, "Another real thing! I am not dead yet! I can still call forth a piece of soul and set it down in colour, fixed forever..." (The Bone People 74). Suddenly she remembers Simon, whom she had forgotten in her self-absorption and his silence, "his self-effacement", she notes, "is perfect" (The Bone People 74). Asking him what he has done, she picks up the pad, on which, to her surprise, he has drawn nothing. Like the Child in An Imaginary Life, Simon's only utterances are directed, not by ego, but by his unfiltered impressions of the natural world. 
Therefore, here appears the difference in Kerewin's and Ovid's attitudes towards the mute child. While Ovid, has, by surrendering his bid for mastery over the Child, taken the first steps towards comprehending his uniqueness, which, with the coming of winter, becomes more readily apparent. While everyone else wraps up in furs, the Child appears not to feel the cold at all, and runs naked into the snow. When Ovid attempts to bring him inside, the Child suddenly reverts to his animal ways, howling and spitting. Ovid is forced, then, to acknowledge:

All these weeks I have been following my own plan for the Child, and have never for one moment thought of him as anything but a creature of my will, a figure of my dream. Now, as he kneels in the snow, howling, tearing his face with his nails, I have a vision of his utter separateness that terrifies me. (An Imaginary Life 106)

Having failed in his attempt to convert the Child into a social being, Ovid does not revoke him, but, following the only other possible course, flees with him beyond the outermost limits of society, into the steppe. In doing so, he announces his commitment to the preservation of their silent communion, at the expense of his own authority

For Kerewin, failure to articulate Simon's existence leads her to despair at what seems to exemplify the ultimate invalidity of all constructions of meaning - including her own art. She writes, "So I exist, a husk that wishes to decay into sweet earth. Writing nonsense in a journal no one ever sees" (The Bone People 261). The absence of an audience clearly contributes to Kerewin's sense of meaninglessness; that she has a captive audience in Simon and Joe fails to register in Kerewin's mind, as they are incapable of giving her the validation she needs. Simon rather confirms her feeling of groundlessness in his ability to generate or recognize meaning. Furthermore, Kerewin's mind, threatens to reduce her already diminished creative energy. Thus, she renounces the ambiguous terms of their relationship, turning with a sense of renewed urgency to her art. which has the advantage of being stable' and substantial, if empty. Showing Joe her old paintings, she explains, "These are the only things in my life that are real to me now. Not people. Joe. Nor relationships. Not families. Paintings. That remind me I could" (The Bone People 264). Thus faced with the 
potential decrease of personal meaning, Kerewin retreats to her old structure of security.

Obviously, Kerewin and Joe do not move far enough to right way, for Joe can think only of a sexual union with Kerewin, something she neither needs nor desires, and Kerewin is not willing enough to risk involvement and hurt for the sake of Simon. Thus, there is the catastrophe, Joe's explosion into violence when Kerewin opts out. Once, acknowledged, however, silence cannot be so easily dismissed. Simon does not immediately understand the terms of his rejection, and, although he has been ordered to stay away, goes to the tower to visit Kerewin. She receives him coldly, and he becomes hysterical, which is followed, at her encouragement, by a nearly fatal beating from Joe that leaves Simon in hospital, Joe in jail, and Kerewin, as the final chapter's title indicates, "at the well-spring of death" (The Bone People 412). She burns her tower to the ground, a gesture of obvious symbolic significance as she destructs her prison. By the end of the novel, there is a movement from psychological fiction to myth. Lawrence Jones, in his essay "Modernism, Myth, and Postmodernism", explains that there has been a mythic undertone all along, especially in the treatment of Simon, around whom have played not only the lights of the secularized myth of the lost heir, but also the more genuine myth of Maui. The myth here, is outward-pointing, attempting to inflate the individual characters to figures in a national myth (204). Each of the three characters is taken through a night journey towards rebirth. Joe moves from prison to a spiritual retreat with the Kaumatua, where he is brought to face his error in attempting to force Kerewin into the mould of a sexual relationship, to expiate it through suffering and service. There he is healed and takes on his prophesied role as keeper of the Maun, the dormant life principle of the land, which he finally takes back to the rined tower. Simon moves from unconsciousness back into the world, and from hospital to orphanage, resisting being taken away from his mission of linking Kerewin and Joe, making his way back to them. Kerewin - knowing now that she has cancer - moves from her destroyed tower to a spiritual retreat facing her own selfishness, repenting, expiating by suffering through her bowel tumour alone, aided only by a mysterious aged figure and a vision of Simon. She returns from that journey, deciding to rebuild her house, not as a lonely tower but as a socially inclusive spiral. There the three can come together as a new kind of 
unit, beyond the sexually-based nuclear family, widening to include Kerewin's family and the community, a model of a new kind of social harmony.

In this last quarter of the novel, then, the characters become the bone people, "the people who make another people" (The Bone People 469), "the heart and muscles and mind of something perilous and new, something. strange and growing and great" ( $p$ The Bone People 2) "the waves of future chance" (The Bone People 406). Behind them lies a national myth: the Maori people had had the chance to be something special, allied with "something very great", but they had "ceased to nurture the land", fought among themselves, lost their mission, and were overcome by the Pakeha (The Bone People 374); the Pakeha completed the Fall "... the forests burned and cut down; the gouges and scars that dams and road works and development schemes had made; the peculiar barren paddocks where alien animals, one kind of crop, grazed imported grasses; the over fertilization, the pollution" (The Bone People 381); the rebirth, must come from a new unity of Maori and Pakeha with each other and the land, and the bone people provide the start. However, the last quarter of the novel does extend itself too far, the characters cannot stand up under the mythic burden placed upon them. The problem is more convincingly presented than the answer, and the characters work better as individuals than as redemptive figures. Thus the ending is more an act of will than something emerging naturally from the rest of the story.

Kerewin's impending death is, like Ovid's, an act - or a surrendering - of will. When he sets out with the Child into the steppe, Ovid merely enacts physically the renunciation his spirit has already declared through his alliance with the Child, "I had", he explains, "to enter the silence to find a password that would release me from my own life" (An Imaginary Life 32). The password emerges, not trom Ovid's attempt to infuse the silence with speech, but from his willingness to literally 'pass' words and allow the silent world the Child has shown him to envelop him. With the surrendering of his voice, Ovid loses his ego, out retains his consciousness; indeed he becomes all consciousness, allowing the universe to filter through him as it does through the Child, in dissolution or the sategories of time and space. This metamorphic moment does ot tinally snable Ovid's identification of, or with, the Child. As he takes what 
he knows is his final step, and lowers himself to the earth, Ovid is aware; of the Child, who is receding into the distance. Though he is capable of calling to him, he does not, for he avers, "to call him back might be to miss the fullness of the moments as it is about to be revealed, and I want so much, at the very end here, to be open to all that it holds for me" (An Imaginary Life 152). In becoming "open" Ovid necessarily relinquishes the system which granted his appellative power. Thus the ending of An Imaginary Life signals, not Ovid's discovery of a language of authenticity, but his recognition that authenticity cannot grounded in any signifying system, and can only finally be articulated in silence.

Kerewin, approaches, but finally avoids such a deconstruction. As she nears death, Kerewin, like Ovid, experiences a moment of extreme consciousness, which is as self-affirming as Ovid's is self-effacing. Lying in bed, she has a sense of being at once bodiless and extremely cold:

\begin{abstract}
Above all, she was incredibly incurably sense-able. To all modes, declensions, conduits and canticles of feeling - she would never, could never, stop being conscious. And thinking of herself. Her gift and her burden. Not bones. (The Bone People 423)
\end{abstract}

This obvious rejection of death accelerated Kerewin's physical and psychological recovery. Her revelation is legitimized by the immediate arrival of a small, dark figure of indeterminate sex, who gives her a restorative drink and disappears. Whatever the curative properties of the drink, there can be no doubt that the mysterious visitor's key role is to provide Kerewin with the spiritual sustenance she has just demonstrated her readiness to receive. Paying attention to what she interprets as the dream's message, Kerewin launches into the resurrection of an old Maori hall near Moerangi, engaging the whole community in her project. Having thus formally reclaimed her Maori roots, she prepares for reconciliation, with two people whose suffering over the preceding months has equalled her own.

After his release from prison, Joe, like Kerewin, was. pulled back from the brink of death through the intervention of a supernatural power, which also entrusts to him a 'gift and burden :onnected with the cultivating of the tragile and badly damaged spirit of the 'and. Joe's and Kerewin's acceptance of this 


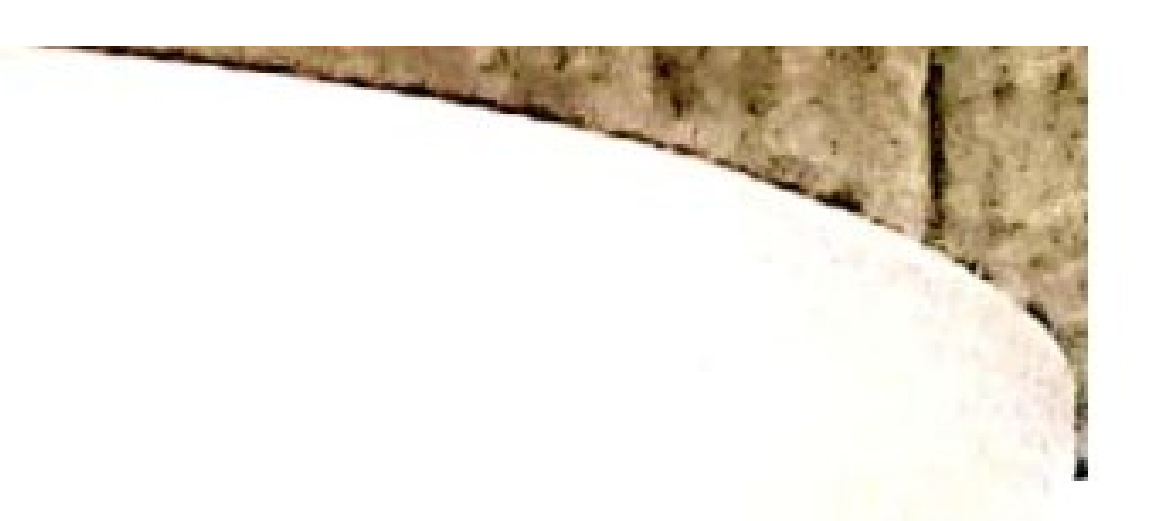

responsibility corresponds fittingly with Simon's discharge from the hospital, and Kerewin's decision to adopt him. After weeks of unconsciousness, Simon has made a miraculous recovery, incurring only a moderate hearing loss, with no apparent intellectual damage. He has sustained no obvious psychological trauma, and is clearly delighted to be reunited with the two people he loves most. Their reunion is finally facilitated by Kerewin's acknowledgment that her life has found new direction, by which she accepts responsibility, assuming the role of leader and "tying up loose ends, making the new whole" (The Bone People 436). In accordance with this last, she is able, finally, by impression of new information, to close the case on Simon's mysterious past. She also learns his 'real' name, which he has shown her in a message formed months previously out of rocks she now sees for the first time. Though his message was unfinished, it contains all Kerewin has to know, that "CLARE WAS HE... ". Writing a final journal entry, Kerewin reflects on the end of her journey, which must be, "not an arbitrary ending... . Something of a tender ritual, an exorcism of all the past despair. A meet end to make a fit beginning" (The Bone People 436). Finally, Kerewin in her tower, now a spiral and filled with people - her family, with whom she has been reconciled, and Joe and Simon, the Maori man and Pakeha child, whose combination with her symbolizes a strengthened alliance between the two races.

Like the end of An Imaginary Life, this resolution has mythic overtones. The difference lies in the way in which myth is presented, and it is here that the role of the mute child becomes particularly significant. The allusion in An Imaginary Life to Ovid's metamorphoses powerfully demonstrates the capacity of the imagination to effect change. At the same time, because An Imaginary Life is, as its title suggests, no more than myth itself, the text draws attention to the provisional nature of the stories we create to explain ourselves to ourselves. This vast, uncultivated area of the 'soul's need', represented psychoanalytically by the gap between self and other, is expressed in the post-colonial society in the space between opposing cultural and linguistic systems. An Imaginary Life would seem to suggest that, if a new post-colonial mythology is to be born, it must be generated, not by a nostalgic return to the 'original' indigenous language, but by an articulation of the space between the voice of the colonizer, and that which the colonizer has suppressed. It is in this space that the Chiid operates, showing 
responsibility corresponds fittingly with Simon's discharge from the hospital, and Kerewin's decision to adopt him. After weeks of unconsciousness, Simon has made a miraculous recovery, incurring only a moderate hearing loss, with no apparent intellectual damage. He has sustained no obvious psychological trauma, and is clearly delighted to be reunited with the two people he loves most. Their reunion is finally facilitated by Kerewin's acknowledgment that her life has found new direction, by which she accepts responsibility, assuming the role of leader and "tying up loose ends, making the new whole" (The Bone People 436). In accordance with this last, she is able, finally, by impression of new information, to close the case on Simon's mysterious past. She also learns his 'real' name, which he has shown her in a message formed months previously out of rocks she now sees for the first time. Though his message was unfinished, it contains all Kerewin has to know, that "CLARE WAS HE... ". Writing a final journal entry, Kerewin reflects on the end of her journey, which must be, "not an arbitrary ending... . Something of a tender ritual, an exorcism of all the past despair. A meet end to make a fit beginning" (The Bone People 436). Finally, Kerewin in her tower, now a spiral and filled with people - her family, with whom she has been reconciled, and Joe and Simon, the Maori man and Pakeha child, whose combination with her symbolizes a strengthened alliance between the two races.

Like the end of An Imaginary Life, this resolution has mythic overtones. The difference lies in the way in which myth is presented, and it is here that the role of the mute child becomes particularly significant. The allusion in An Imaginary Life to Ovid's metamorphoses powerfully demonstrates the capacity of the imagination to effect change. At the same time, because An Imaginary Life is, as its title suggests, no more than myth itself, the text draws attention to the provisional nature of the stories we create to explain ourselves to ourselves. This vast, uncultivated area of the 'soul's need', represented psychoanalytically by the gap between self and other, is expressed in the post-colonial society in the space between opposing cultural and linguistic systems. An Imaginary Life would seem to suggest that, if a new post-colonial mythology is to be born, it must be generated, not by a nostalgic return to the 'original' indigenous language, but by an articulation of the space between the voice of the colonizer, and that which the colonizer has suppressed. It is in this space that the Chiid operates, showing 
Ovid the limits of his own understanding, and inviting him to take the imaginative leap necessary to create a new form.

The Bone People, like An Imaginary Life, is about the realization of artistic and human potential. While, however, Ovid accepts ultimate responsibility for the world he constructs, Kerewin's constructions are sanctioned by an appeal to the Transcendental Signified of the Maori myth of origins. In other words, Malouf penetrates myth to its source in lack, which, Ovid death exemplifies, while Hulme presents myth as first principle. Kerewin, then, does not die, but is pulled from the "well spring of death". Essential to that vision is her assimilation of Simon, whose recent scars she has penetrated to the original truth of his existence, which is contained in his real name, Clare. In offering Joe and Simon "that unlikely gift, her name" (The Bone People 444), Kerewin has not merely reappropriated her lost Maoritanga, but has included it into her own vision of living with, the implicít approval of the Maori spirit who saved her.

However, neither the final section of the book, the greater part of which is occupied with the Maori myth, nor the earlier chapters seem to provide a development towards, such a resolution. The greatest hindrance towards such a restoration of collective meaning is Simon, whose indeterminate origins and silence weaken the definitive authority of all communicative systems. In failing to acknowledge the randomness of all endings and beginnings, Kerewin would seem to be emphasizing her own artistic sovereignty without acknowledging its source in emptiness - just as her social authority is legitimized only by eliminating the silent subject that facilitated it. As Ovid's metamorphosis demonstrates, the birth of a new form is dependent upon the surrendering of authority, in acknowledging of the absence of a legitimizing voice. Articulated by the child's absence, this absence infuses the space within which the artist addresses the post-colonial audience, transforming the landscape of artistic exchange from, a field of mutually confirmed meanings to a wilderness of dialogical possibilities. 


\section{Works Cited}

"Keri Hulme". Bateman Encyclopedia of New Zealand. Auckland, New Zealand: Bateman Publishing Co, 1986. 579.

"Keri Hulme." Contemporary Literary Criticism: Yearbook 1985. Vol. 39. Detroit, Michigan: Gale Research Co, 1986. 158-167.

Hansson, Karin. Sheer Edge: Aspects of Identity in David Malouf's Writing. Sweden: Lund UP, 1991.

Hulme, Keri. The Bone People. London: Picador, 1986.

Jones, Lawrence, ed. Barbed Wire and Mirrors: Essays on New Zealand Prose. University of Otago Press, 1987.

Malouf, David. An Imaginary Life. Sydney: Picador, 1978.

Nettelbeck, Amanda. Reading David Malouf. Australia: University of Westem Australia, 1995.

O'Brien, Susie. "Raising Silent Voices: The Role of the Silent Child in $d n$ Imaginary Life and The Bone People". Span 30 (1990): 79-91. 
Lamees Mohamed El-Gafy

Assistant Professor

English Dept.

Faculty of Al-Alsun

Minia University, A.R.E

\section{Abstract \\ The Language of Silence in Post-Colonial Writing: \\ David Malouf's An Imaginary Life \& \\ Keri Hulme's The Bone People}

Traditionally silence is perceived as withdrawal or as a withholding of meaning, hence the desire to break that silence in order to recover its hidden significance. The producers of post-colonial writing are burdened by a constant awareness that the cultural myths that inform their writing and the language they use are vehicles for a provisional truth, which has been dictated by the demands of the empire. The necessary abrogation of the received language creates, for the postcolonial writer, a crisis of authority, which finds textual representation in figures of silence. Keri Hulme's The Bone People and David Malouf's An Imaginary Life, both thematize the writer's necessary quest beyond the boundaries of conventional language through the relationship of an artist-protagonist with a mute child. The progress of this interaction may be seen as an emblem of the writer's examination of language and related revision of the dialogue between self and other which constitutes the artistic exchange. 


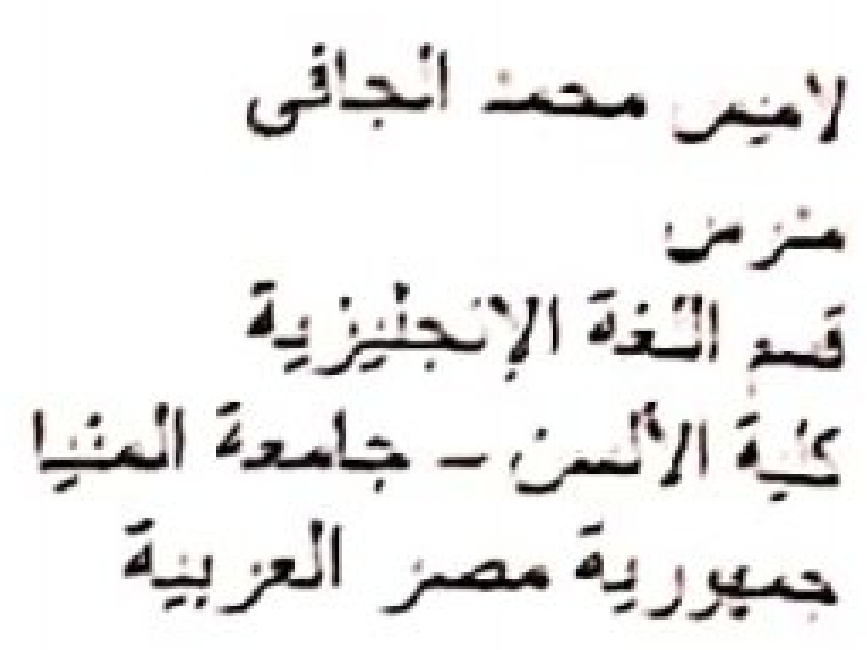

\section{ملخص البحث}

لغة الصمت فى أدب مـا بعد الاستعمار : "حياة خيالية"

\section{لايفيد معلوف و "الهياكل العظميةه" لكيرى هولم}

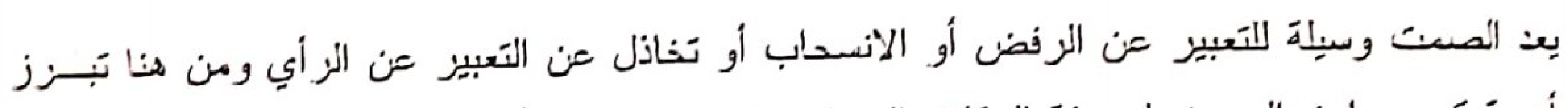

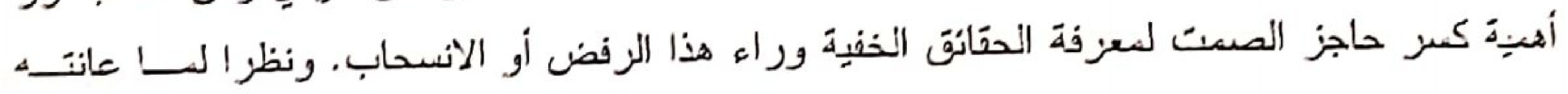

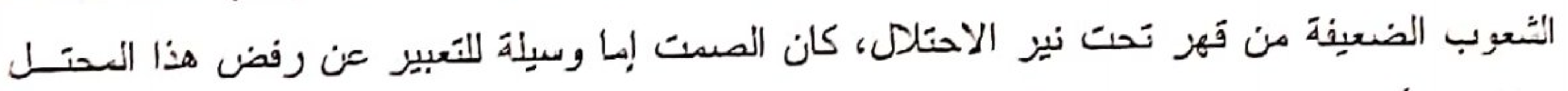

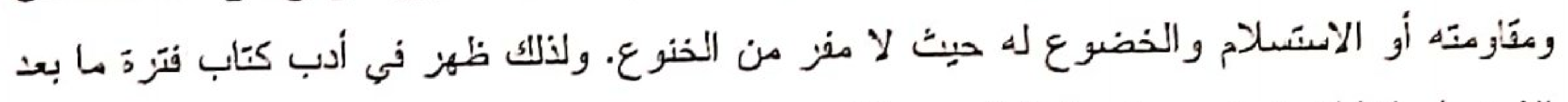

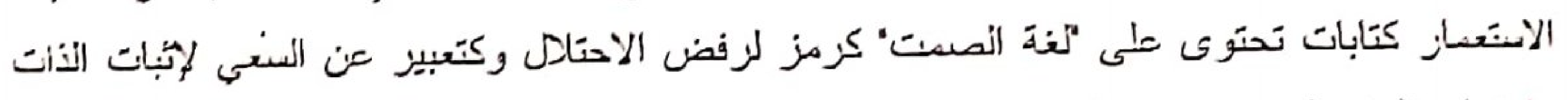

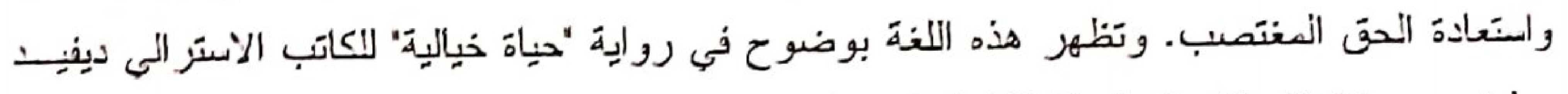

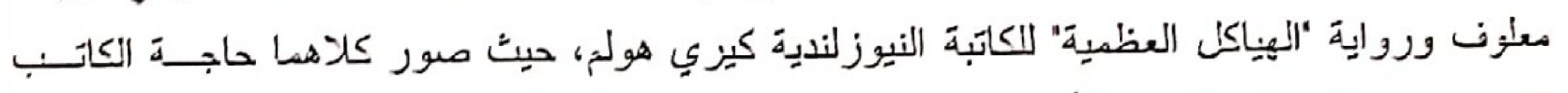

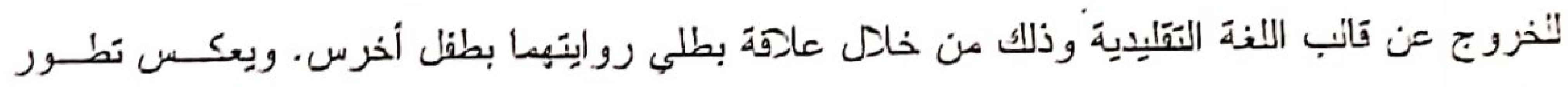

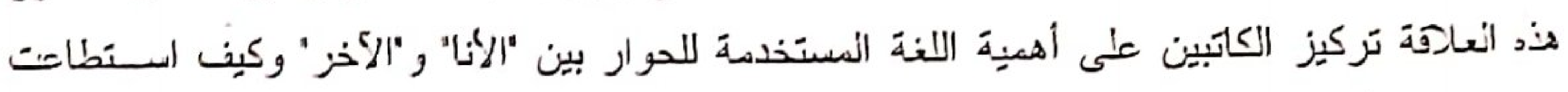

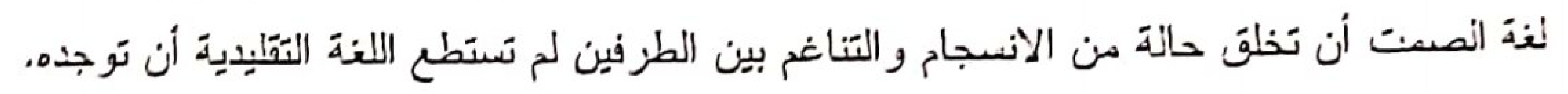

